\title{
Passado o futuro: o ideário reformista na saúde
}

Frederico Jorge Vieira Nitão

Curso: Doutorado em Sociologia

Data da defesa: 27 de agosto de 2009

Orientadora: Prof ${ }^{\mathrm{a}} \mathrm{Dr}^{\mathrm{a}}$ Fernanda Antônia Fonseca Sobral

\section{Resumo}

Passados 23 anos da VIII Conferência Nacional de Saúde e 21 anos da promulgação da Carta Magna, justifica-se uma análise sobre o ideário da Reforma Sanitária Brasileira, na perspectiva de verificar sua viabilização concreta. Desse modo, o objetivo da presente investigação é analisar a emergência e o desenvolvimento de um projeto político-ideológico contra-hegemônico que logrou legitimar-se e, posteriormente, com sua institucionalização, via Sistema Único de Saúde, criou as condições para a promoção da universalização das políticas sociais. Busca-se, a partir desse ideário em uma formação capitalista e conservadora, compreender seus fundamentos doutrinários sob o enfoque da práxis. Defende- 
se a tese segundo a qual o ideário da Reforma Sanitária Brasileira constitui-se em fenômeno social e histórico e, como tal, representa uma reforma social.

O estudo tem como hipótese que a Reforma Sanitária Brasileira, embora proposta como práxis setorial e teorizada para alcançar a democratização e somente em sua vigência plena poderia viabilizarse promovendo a inclusão social com vistas à cidadania, apresentaria como desfecho uma reforma parcial, aquém do prometido setorial e socialmente. Realizou-se um estudo da implantação e implementação do Sistema Único de Saúde, a partir de pesquisa documental, em duas conjunturas, tendo como componente descritivo o período compreendido pela formulação do ideário, a difusão do projeto, a arregimentação de militantes, a ocupação do aparelho de Estado com vistas à legitimação e legalização do ideário, e como componente explanatório, a análise do desenvolvimento institucional da reforma pretendida, recorrendo ao referencial teórico de Giddens, Offe, Rosanvallon, particularmente às categorias de globalização econômica, responsabilização e atribuição individual e comunitária, novas relações entre Estado, sociedade civil e mercado, pulverização do modo de produção e novas relações de trabalho.

Os resultados identificam o êxito parcial do ideário da Reforma Sanitária Brasileira como a ampliação do acesso e a descentralização, tendo como contrapartida a persistência da concentração do poder na União Federal. Constata-se que os antigos protagonistas da Reforma Sanitária Brasileira, agora gestores do sistema, evocam os problemas de saúde e da organização dos serviços e escamoteiam as soluções. Procura-se acentuar a relevância da ausência do "sujeito coletivo" na consolidação de uma Reforma Democrática da Saúde, mediante alterações da correlação de forças, desequilibrando o binômio conservação-mudança em benefício do segundo e promovendo uma política de proteção social maciçamente inclusiva e cidadã.

Palavras-chave: saúde pública; política de saúde; medicina social; reforma sanitária; Sistema Único de Saúde; Brasil. 